\title{
Long Term Effect of Integrated Weed Management on Growth and Yield Attributes in Chilli
}

\author{
J. Cheena ${ }^{1}$, P. Saidaiah ${ }^{2 *}$ and A. Geetha ${ }^{3}$ \\ ${ }^{1}$ Department of Vegetable Science, JVR- Horticultural Research Station, Sri Konda Laxman \\ Telangana State Horticulture University, Malyal, Warangal district, Telangana, India \\ ${ }^{2}$ Department of Genetics and Plant Breeding, College of Horticulture, SKLTSHU, \\ Rajendranagar, Hyderabad-500030, Telangana, India \\ ${ }^{3}$ Department of Crop Physiology, Regional Agricultural Research Station, Palem, \\ Nagarkurnool District, Telangana, India \\ *Corresponding author
}

\begin{tabular}{|c|}
\hline Keywords \\
\hline $\begin{array}{l}\text { Herbicides, Inter } \\
\text { cultivation, } \\
\text { Integrated weed } \\
\text { management, Chilli. }\end{array}$ \\
\hline Article Info \\
\hline $\begin{array}{l}\text { Accepted: } \\
\text { 14 September } 2017 \\
\text { Available Online: } \\
10 \text { October } 2017\end{array}$ \\
\hline
\end{tabular}

A B S T R A C T

An experiment was conducted in JVR- Horticultural Research Station, Malyal to evaluate the efficacy of different herbicides and integrated weed management strategies for weed control on growth and yield attributes in chilli during kharif, 2013-2015. Among the treatments, plant height was minimum in Glyphosate @ 1.51 /ha directed spray 25 and 50 DAT followed by inter cultivation at 25 and 50 DAT (87.08), Pendimethalin C.S as preemergence @ 0.70 1/ha and quizalofopethyl @ 50 ml/ha at 15-20 DAT (79.15) and lowest was recorded in Oxadiargyl as pre-emergence @ $90 \mathrm{ml} / \mathrm{ha}$ followed by propaquizafop @ $62.51 /$ ha at $15-20$ DAT (65.14). Number of primary branches significant and highest in inter cultivation at 25 and 50 DAT (5.18) followed by Glyphosate @ 1.5 1/ha directed spray at 25 and 50 DAT, whereas lowest was reported in Oxadiargyl as pre-emergence @ 90 1/ha followed by quizalofopethyl @ 50ml/ha at 15-20 DAT and pendimethalin C S as pre-emergence @ 0.70 1/ha and propaquizafop@62.5 ml/ha at 15-20 DAT (3.62). Plant spread was noticed in Glyphosate @ 1.5 1/ha directed spray at 25 and 50 DAT followed by inter cultivation at 25 and 50 DAT (20.51), Pendimethalin C.S as pre-emergence @ 0.70 1/ha and propaquizafop @ $62.5 \mathrm{ml} /$ ha at 15-20 DAT (19.82). Number of fruits were highest in Pendimethalin C.S as pre-emergence @0.70 1/ha followed by quizalofopethyl @ 50 $\mathrm{ml} / \mathrm{ha}$ at 15-20 DAT (186.58), Oxadiargyl as pre-emergence @ $90 \mathrm{ml} / \mathrm{ha}$ and Propaquizafop @ 62.5 1/h at 15-20 DAT (184.91). Yield per plant (g) was highest in Pendimethalin C.S as pre-emergence @ 0.70 1/ha followed by quizalofopethyl@ $50 \mathrm{ml} / \mathrm{ha}$ at 15-20 DAT, (216.02), Glyphosate@ 1.5 1/ha directed spray 25 and 50 DAT and inter cultivation at 25 and 50 DAT (208.17). Significantly and highest yield (t/ha) was recorded in Glyphosate @ 1.5 1/ha directed spray 25 and 50 DAT followed by inter cultivation at 25 and 50 DAT (4.00 t/ha) Higher weed control efficiency and B C ratio were recorded by the same treatments. These results are useful choosing for efficient and economic method of weed control.

\section{Introduction}

Chilli (Capsicum annuum L.) is the source of natural pungent compounds (capsaicin), colouring compounds (capsorubin) and vitamin C. It is known for its commercial and 
therapeutic value. India stands first in chilli cultivation covering 45 per cent area of the world, but the productivity of dry chilli is lower $(0.9 \mathrm{t} / \mathrm{ha})$ as compared to world's average $(2.0 \mathrm{t} / \mathrm{ha})$. There is tremendous demand for Indian chillies in the International market that provides wide scope to increase export (Deshpande, et al., 2006).

Chilli faces severe competition with the weeds during its initial stages of crop growth due to application of higher doses of fertilizers and frequent irrigation. Uncontrolled weed growth in chilli is due to its inherent characteristics such as short stature, sparse foliage, shallow root system and extremely slow initial growth results in 49 to 51 per cent of yield reduction. Hand weeding, though effective is laborious, cumbersome and under many situations it becomes uneconomical.

Herbicides have become important tool for weed control, but it is not effective in controlling all the weeds present in the crop. Hence, the present study was undertaken to find out a suitable package for efficient control of weeds in chilli crop.

\section{Materials and Methods}

The experiment was conducted consequently for three years during kharif seasons of 2013, 2014 and 2015 at the JVR-Horticulture Research Station, Warangal District. Teja variety of chilli was planted in second fortnight of June at $60 \times 60 \mathrm{~cm}$. The experiment was laid out in Randomized Block Design with two replications. Thirteen treatments of the present study comprised of $\mathrm{T}_{1}$ : Pendimethalin C.S as pre-emergence @0.70 1/ha + one hand weeding at $45 \mathrm{DAT}$, $\mathrm{T}_{2}$ : Oxadiargyl as pre-emergence @90 1/ha + one hand weeding at 45 DAT, $\mathrm{T}_{3}$ : Oxyfluorfen pre-emergence @ 0.15 1/ha + one hand weeding at $45 \mathrm{DAT}_{\mathrm{T}}$ : Pendimethalin
C.S as pre-emergence @ 0.70 1/ha followed by quizalofopethyl @ $50 \mathrm{ml} / \mathrm{ha}$ at 15-20 DAT, $\mathrm{T}_{5}$ : Oxadiargyl as pre-emergence @ 90 1/ha followed by quizalofopethyl @ 50ml/ha at 15 20 DAT, $\mathrm{T}_{6}$ : Oxyfluorfen pre-emergence @ 0.15 1/ha followed by quizalofopethyl @ 50 $\mathrm{ml} / \mathrm{ha}$ at $15-20 \mathrm{DAT}, \mathrm{T}_{7}$ : Pendimethalin C.S as pre-emergence @ 0.70 1/ha followed by propaquizafop@62.5 m. 1/ha at 15-20 DAT, $\mathrm{T}_{8}$ : Oxadiargyl as pre-emergence @90 ml/ha followed by propaquizafop @62.5 1/ha at 1520 DAT, T9: Oxyfluorfen pre-emergence @ 0.15 1/ha followed by propaquizafop @62.5 $\mathrm{ml} /$ ha at 15-20 DAT, T 10 : Glyphosate@1.5 1/ha directed spray at 25 and 50 DAT, $\mathrm{T}_{11}$ : Inter cultivation at 25 and $50 \mathrm{DAT}, \mathrm{T}_{12}$ : Hand weeding three times at 20,40 and 60 DAT and $\mathrm{T}_{13}$ - Manual weed control. Data were taken on five randomly selected plants for plant height $(\mathrm{cm})$, number of primary branches per plant, plant spread, number of fruits per plant, yield/plant (g) and yield ( $\mathrm{t} / \mathrm{ha}$ ). The mean values of five plants used for recording observations were computed for each of the six characters on growth and yield for each of the genotype in each replication and were subjected to statistical analysis (Panse and Sukhatme, 1985.).

The dominant weed flora of the experimental field consisted of grassy weeds [Cynodon dactylon (7\%), Dinebra retroflexa (10\%), Eleusine indica (5\%) and Setaria glauca (11\%)], sedge weed [Cyperus rotundus (9\%)] and broad-leaved weeds (BLW) [Phyllanthus niruri L. (4\%), Physalis minima L. (3\%) and Portulaca oleracea L. (13\%) Convolvulus arvensis L. (8\%), Commelina benghalensis L. (18\%) and Ageratum conyzoides L. (11\%)].

\section{Results and Discussion}

Analysis of variance of treatments revealed that there is significant amount of variation among the different weed control treatments. 
Table.1 Effect of integrated weed management on growth and yield in chili

(Pooled data from kharif, 2013-14 to 2015-16)

\begin{tabular}{|c|c|c|c|c|c|c|}
\hline Treatments & $\begin{array}{c}\text { Plant height } \\
(\mathrm{cm})\end{array}$ & $\begin{array}{c}\text { Number of } \\
\text { Primary } \\
\text { branches per } \\
\text { plant } \\
\end{array}$ & $\begin{array}{c}\text { Plant } \\
\text { spread }\end{array}$ & $\begin{array}{l}\text { Number } \\
\text { of fruits } \\
\text { per plant }\end{array}$ & $\begin{array}{c}\text { Yield/Plant } \\
\text { (g) }\end{array}$ & $\begin{array}{l}\text { Yield } \\
\text { (t/ha) }\end{array}$ \\
\hline $\begin{array}{l}\mathrm{T}_{1}: \text { Pendimethalin C.S as pre- } \\
\text { emergence } @ 0.701 / \mathrm{ha}+\text { one hand } \\
\text { weeding at } 45 \mathrm{DAT}\end{array}$ & 76.25 & 3.88 & 16.87 & 175.93 & 181.17 & 3.26 \\
\hline $\begin{array}{l}\mathrm{T}_{2:} \text { Oxadiargyl as pre-emergence } \\
@ 90 \mathrm{l} / \mathrm{ha}+\text { one hand weeding at } \\
45 \mathrm{DAT}\end{array}$ & 76.63 & 3.72 & 17.31 & 174.69 & 180.19 & 3.13 \\
\hline $\begin{array}{l}\mathrm{T}_{3}: \text { Oxyfluorfen pre-emergence @ } \\
0.15 \mathrm{l} / \mathrm{ha}+\text { one hand weeding at } \\
45 \mathrm{DAT}\end{array}$ & 78.14 & 3.87 & 16.74 & 166.80 & 182.52 & 3.27 \\
\hline $\begin{array}{l}\mathrm{T}_{4} \text { : Pendimethalin C.S as pre- } \\
\text { emergence @ } 0.70 \text { 1/ha followed } \\
\text { by quizalofopethyl@ } 50 \mathrm{ml} / \mathrm{ha} \text { at } \\
15-20 \text { DAT }\end{array}$ & 79.15 & 3.76 & 16.65 & 186.58 & 216.02 & 2.79 \\
\hline $\begin{array}{l}\mathrm{T}_{5} \text { : Oxadiargyl as pre-emergence } \\
@ 90 \quad 1 / \mathrm{ha} \text { followed by } \\
\text { quizalofopethyl @ } 50 \mathrm{ml} / \mathrm{ha} \text { at } 15- \\
20 \mathrm{DAT}\end{array}$ & 73.52 & 3.62 & 17.09 & 163.34 & 174.44 & 3.22 \\
\hline $\begin{array}{l}\mathrm{T}_{6:} \text { Oxyfluorfen pre-emergence @ } \\
0.15 \quad 1 / \text { ha followed by } \\
\text { quizalofopethyl @ } 50 \mathrm{ml} / \mathrm{ha} \text { at } 15- \\
20 \mathrm{DAT}\end{array}$ & 70.03 & 3.69 & 15.58 & 160.43 & 174.09 & 3.18 \\
\hline $\begin{array}{l}\mathrm{T}_{7}: \text { Pendimethalin C.S as pre- } \\
\text { emergence @ } 0.701 / \mathrm{ha} \text { followed } \\
\text { by propaquizafop @ } 62.5 \mathrm{~m} .1 / \mathrm{ha} \\
\text { at } 15-20 \mathrm{DAT}\end{array}$ & 75.07 & 3.62 & 19.82 & 173.18 & 181.29 & 3.27 \\
\hline $\begin{array}{l}\mathrm{T}_{8:} \text { Oxadiargyl as pre-emergence } \\
@ 90 \mathrm{ml} / \mathrm{ha} \text { followed by } \\
\text { propaquizafop @62.5 1/ha at } 15- \\
20 \mathrm{DAT}\end{array}$ & 65.14 & 3.87 & 16.99 & 184.91 & 186.31 & 3.36 \\
\hline $\begin{array}{l}\mathrm{T}_{9:} \text { Oxyfluorfen pre-emergence @ } \\
0.15 \quad 1 / \mathrm{ha} \text { followed by } \\
\text { propaquizafop @ } 62.5 \mathrm{ml} / \mathrm{ha} \text { at } 15- \\
20 \text { DAT }\end{array}$ & 76.62 & 4.07 & 18.10 & 165.65 & 173.85 & 3.27 \\
\hline $\begin{array}{l}\mathrm{T}_{10} \text { : Glyphosate } @ 1.5 \quad \text { 1/ha } \\
\text { directed spray at } 25 \text { and } 50 \mathrm{DAT}\end{array}$ & 87.08 & 4.80 & 20.51 & 182.49 & 208.17 & 4.00 \\
\hline $\begin{array}{l}T_{11:} \text { Inter cultivation at } 25 \text { and } 50 \\
\text { DAT }\end{array}$ & 71.73 & 5.18 & 18.46 & 173.58 & 196.55 & 3.87 \\
\hline $\begin{array}{l}\mathrm{T}_{12:} \text { Hand weeding three times at } \\
20,40 \text { and } 60 \mathrm{DAT}\end{array}$ & 68.28 & 3.71 & 16.97 & 167.26 & 170.52 & 3.12 \\
\hline $\mathrm{T}_{13:}$ Manual weed control & 73.71 & 4.11 & 15.71 & 148.05 & 159.21 & 2.88 \\
\hline $\mathrm{CV} \%$ & 14.08 & 2.56 & 12.49 & 4.62 & 3.28 & 3.77 \\
\hline $\mathrm{CD}(5 \%)$ & N.S & 0.22 & N.S & 17.22 & 13.13 & 0.27 \\
\hline
\end{tabular}


Among the treatments, plant height was minimum (Table 1) with the herbicide Glyphosate @ 1.5 1/ha directed spray at 25 and 50 DAT followed by Inter cultivation at 25 and 50 DAT (87.08), Pendimethalin C.S as pre-emergence $@ 0.70 \quad 1 /$ ha and Quizalofopethyl@ $50 \mathrm{ml} / \mathrm{ha}$ at 15-20 DAT, (79.15). Lowest plant height was recorded with Oxadiargyl as pre-emergence @90 ml/ha followed by propaquizafop @62.5 1/ha at 1520 DAT (65.14). Number of primary branches were significant and highest in Inter cultivation at 25 and 50 DAT (5.18) followed by glyphosate @ 1.5 1/ha directed spray at 25 and 50 DAT and inter cultivation at 25 and 50 DAT (4.80) and lowest was recorded with herbicide Oxadiargyl as pre-emergence @90 1/ha, quizalofopethyl @ 50ml/ha at 15-20 DAT, pendimethalin C S as pre-emergence @ 0.70 1/ha and Propaquizafop @62.5 ml/ha at 15-20 DAT (3.62). Plant spread was higher in Glyphosate @ 1.5 1/ha directed spray 25 and 50 DAT followed by Inter cultivation at 25 and 50 DAT (20.51), pendimethalin c.s as pre-emergence @0.70 1/ha and propaquizafop @6 $62.5 \mathrm{ml} / \mathrm{ha}$ at 15-20 DAT (19.82), while lowest was in herbicide oxyfluorfen preemergence @ 0.15 1/ha followed by quizalofopethyl@50 ml/ha at 15-20 DAT (15.58). Reduced crop weed competition due to effective control of weeds by various integrated weed management practices resulted in better utilization of growth factors by crop and this resulted in its better growth and development. This may be ascribed to fact that the effective control of weeds led to the favourable environment for growth and photosynthetic activity of the crop. These results are in accordance with the findings of Singh et al., (1997) and Mekki et al., (2010).

Number of fruits were more in herbicide Pendimethalin C.S as pre-emergence @0.70 1/ha followed by Quizalofopethyl@ 50 ml/ha at 15-20 DAT (186.58), Oxadiargyl as preemergence @90 ml/ha and Propaquizafop
@ 62.5 1/ha at 15-20 DAT (184.91), while lowest was recorded in manual weed control (148.05). The significant increase in fruit number in the treatments could be attributed to lower weed count, weed dry weight and higher weed control efficiency which ultimately resulted in better crop growth leading to higher dry matter production plant. This in turn was responsible for greater translocation of photosynthates resulting in increased fruit number.

Yield per plant recorded with Pendimethalin C.S as pre-emergence @ 0.70 1/ha followed by quizalofopethyl@ $50 \mathrm{ml} / \mathrm{ha}$ at 15-20 DAT, (216.02), Glyphosate @ 1.5 1/ha directed spray at 25 and 50 DAT and Inter cultivation at 25 and 50 DAT (208.17) and lowest was recored in manual Weed Control treatment (159.21). Significantly highest yield (t/ha) was recorded in Glyphosate @ 1.5 1/ha directed spray at 25 and 50 DAT followed by Inter cultivation at 25 and 50 DAT (4.00 t/ha), whereas lowest yield was recorded in Pendimethalin C.S as pre-emergence @0.70 1/ha followed by Quizalofopethyl@ 50 ml/ha at 15-20 DAT, (2.79 t/ha). Weed free check recorded highest values of chilli yield, may be due to least competition on offered by weeds. The rate of NPK absorption cumulatively helped the crop plants to produce more surface area for high photosynthetic rate as well as maximum translocation of photosynthates from source to sink, subsequently resulted in improvement in yields. Ved Prakash et al., (2003) also reported similar findings in chilli. Kunti et al., (2012) also reported significant increase in fruit yield of chilli. These finding are in agreement with the earlier result of Deshpande et al., (2006), Rajput (2003) and Saini and Walia (2012).

The study concluded that Pendimethalin C.S as pre-emergence @0.70 1/ha followed by quizalofopethyl@ 50 ml/ha at 15-20 DAT, 
Glyphosate@1.51/ha directed spray at 25 and 50 DAT and Inter cultivation at 25 and 50 DAT (208.17) are the best for efficient control of weeds in chilli.

\section{References}

Deshpande, R. M., Pawar, W. S., Mankar, P. S., Bobade, P. N. and Chimote, A. N., 2006. Integrated weed management in rainfed cotton. Indian J. Agron., 551(1): 68-69.

Kunti, Sharma G and Singh HP. 2012. Weed management practices on growth and yield of winter season brinjal under Chhattisgarh plain conditions. Ind. J. Agron. Weed Sci. 44(1): 18-20.

Mekki, B.B., Faida AA and Kowthar G. 2010. Effect of weed control treatments on yield and seed quality of some canola cultivars and associated weeds in newly reclaimed sandy soils. Am. J. Agric. Env. Sci. 7(2): 202-209.

Rajput, H.D., Singh K and Kushwha HS. 2003. Integrated weed management in chilli. Ind. J. Agron. 48(2): 136-138.

Saini, M.K., and Walia US. 2012. Effect of land configuration and weed management in onion. Ind. J. Agron.57 (3): 275-278.

Singh, V., Bisen RK, and Agrawal HP. 1997. A note on weed control studies in brinjal. Veg. Sci, 24(2): 162- 163.

Ved Prakash, Pandey, A. K., Singh R. D. and H. S. Gupta, 2003. Integrated weed management in chilli under Mid -Hill conditions of North- Western Himalayas. Indian J. Agron., 48 (2): 139-141.

\section{How to cite this article:}

Cheena, J., P. Saidaiah and Geetha, A. 2017. Long Term Effect of Integrated Weed Management on Growth and Yield Attributes in Chilli. Int.J.Curr.Microbiol.App.Sci. 6(10): 1504-1508. doi: https://doi.org/10.20546/ijcmas.2017.610.179 